\title{
Sürdürülebilir Mimarlık Kapsamında Akılı Cephe Sistemlerinin İncelenmesi
}

\author{
${ }^{* 1}$ Emine Merve Okumuş \\ ${ }^{* 1}$ Mimarlık ve Tasarım Fakültesi, Mimarlık Bölümü, Fatih Sultan Mehmet Vakıf Üniversitesi, Türkiye
}

\section{Özet}

Endüstri devrimi ve dünya savaşlarından sonra nüfustaki hızlı artış, kentleşme ve sanayileşme gibi faaliyetlerle doğal kaynakların aşırı ve bilinçsiz kullanılması ciddi çevre sorunlarına sebep olmuştur. Çevre sorunlarını önleyebilmek amacıyla ülkeler tarafından sürdürülebilir kalkınma fikri geliştirilmiştir. Çevre sorunlarında yapı faaliyetlerinin etkisinin büyük bir paya sahip olmasından dolayı enerji verimliliği için yeni yapı teknolojileri ve malzemeler üzerine çalışmalar yapılmaktadır. Çalışma kapsamında sürdürülebilirlik kavramıyla geliştirilen akıllı cephe sistemleri incelenmiştir. Akıllı cephe sistemleri değişen dış ortam koşullarına cevap vererek mekân içerisinde kullanıcı konforunu en üst seviyede olmasını sağlayan ve enerji tüketimini minimum seviyede tutabilen sistemlerdir. Çalışmanın amacı akıllı cephe sistemlerinin sürdürülebilirliğe olan katkı düzeylerinin araştırılmasıdır. Çalışma kapsamında akıllı cephe sistemlerinin cephe kuruluş düzenleri, kullanılan bileşenler ve cepheye entegre edilen aktif sistemler araştırılmıştır. Dünya'da bulunduğu çevre koşullarına uyumlu olarak tasarlanmış akıllı cephe sistemleri incelendikten sonra akıllı cephe sistemlerinin binanın enerji tüketimi, karbondioksit salınımı, görsel konforu vb. etkileri ile sürdürülebilir kalkınmaya katkı düzeyleri değerlendirilmiştir.

Anahtar Kelimeler: Akıllı cephe sistemleri, Sürdürülebilir mimarlık, Enerji verimliliği

\begin{abstract}
After the industrial revolution and world wars, the rapid increase in population, urbanization, and industrialization and excessive and unconscious use of natural resources caused severe environmental problems. To prevent environmental problems, countries have developed the idea of sustainable development. Since the impact of building activities on environmental problems has a large share, studies have been carried out on new building technologies and materials for energy efficiency. Within the scope of the study, intelligent façade systems developed with the concept of sustainability were examined. Intelligent façade systems are systems that respond to changing outdoor conditions to ensure the highest level of user comfort within space and can keep energy consumption to a minimum. The study aims to investigate the levels of contribution of intelligent façade systems to sustainability. Within the scope of the study, the façade organization layouts of intelligent façade systems, the components used, and active systems integrated into the façade were investigated. After examining intelligent façade systems designed to comply with the environmental conditions, the intelligent façade systems are building energy consumption, carbon dioxide emissions, visual comfort, etc. levels of contribution to sustainable development have been evaluated.
\end{abstract}

Keywords: Intelligent facade systems, Sustainable architecture, Energy efficiency

\section{Giriş}

İnsanoğlu yeryüzünde var olduğu ilk zamanlarda çevreye uyumlu şekilde yaşamlarını sürdürürken yerleşik hayata geçilmesiyle doğa üzerinde bölgesel tahribatlar başlamıştır. Endüstri devrimiyle birlikte gelişen teknolojilerle üretim, sanayi ve kentleşme gibi faaliyetlerin artması ve bu faaliyetlerde fosil yakıtların kullanılmasından dolayı doğaya verilen tahribatlar küresel bir sorun

*Corresponding author: Address: Mimarlık ve Tasarım Fakültesi, Mimarlık Bölümü, Fatih Sultan Mehmet Vakıf Üniversitesi, Türkiye. E-mail address: emokumus@fsmvu.edu.tr, Phone: +902125218100 
haline gelmiştir. 1970'lerde yaşanan enerji krizi sonucunda kullanılan yenilenemez enerji kaynaklarının tükeneceği gerçeği ile yapı sektörü başta olmak üzere birçok alanda yenilebilir enerji kaynaklarını ve enerjiyi daha etkin şekilde kullanabilmeye yönelik çalışmalar yapılmıştır. İlk zamanlarda pasif tasarım ilkelerine dayanan enerji etkin bina tasarımı, enerji yönetimi sağlayan mekanizmalara sahip akıllı bina fikrinin ortaya çıkmasına zemin oluşturmuştur. Akıllı binalar, zaman içerisinde farklılaşan gereksinimlere ve gelişen teknolojilere paralel olarak değişen iç ve diş ortam koşullarını bilgisayar destekli sistemlerle algılayan ve uygun koşullara göre değişebilen dinamik mimari gelişmeye başlamıştır $[1,2]$. Bu çalışmalar kapsamında geliştirilen akıllı cephe sistemleri çalışma kapsamında incelenmiştir.

\section{Akıllı Cephe Sistemleri}

Akıllı bina cepheleri değişen dış ortam koşullarına cevap vererek mekân içerisinde kullanıcı konforu için gerekli 1şık, 1sı, ses ve hava kalitesini en üst seviyede sağlarken enerji tüketimini minimum seviyede tutabilen sistemlerdir. Başlangıçta iç ve dış iklim arasındaki ilişki; kullanıcı tarafından panjurlar, jaluziler ve pencereler aracılığıyla sağlanırken, akıllı binalar ile bu görevi otomatik olarak gerçekleştiren sistemler kullanılmaya başlanmıştır [3, 4]. Bu sistemlerin gelişimi ilk kez 1970 yılında Negroponte tarafından "çevresel koşullara yanıt veren mimarlık" kavramı ile ortaya çıkmıştır ve daha sonra "çevresel koşullara göre değişim göstererek uyum sağlayan mimarlık' fikri gelişmiştir. Kendini çevresel koşullara uyarlayan ilk akıllı yapı cephesi örneği olarak mimar Jean Nouvel tarafından Paris'te 1987 yılında tamamlanan Arap Dünyası Enstitüsü binası örnek gösterilmektedir [5,6]. Akıllı cephe sistemlerinin fonksiyonlarını bulunduğu kentsel ve coğrafi konuma göre; gün 1şığını artırması ya da azaltması, havalandırma, 1sıyı toplaması ya da uzaklaştırması, elektrik üretmesi vb. özelliklere sahip olması istenmektedir. Akıllı cephe sistemlerinden istenen fonksiyonlara göre cam türleri, güneş kontrol elemanları ve yapıya entegre aktif sistemler içinden seçim yapılarak cephe tabaka sayısına ve düzenine karar verilmektedir.

\subsection{Tabaka Sayılarına göre Akıllı Cephe Sistemleri}

Akıllı cephe sistemleri tabakalarına göre tek tabakalı ve çift tabakalı akıllı cephe sistemleri olarak iki gruba ayrılmaktadır. Tek tabakalı cepheler, genellikle tümü aynı düzlemde yer alan şeffaf ve opak elemanlardan oluşmaktadır. En basit formu, pencere ve masif duvar yüzeyinden meydana gelmektedir [4]. Tek tabakalı akıllı cephelerde istenilen düzeyde güneş ve 1sı kontrolünün sağlanabilmesi için kullanılan camın türü ve kalınlığı, tabaka sayısı, tabakalar arası mesafe, ara dolgu gazı, cam yüzeyine uygulanan kaplama malzemesi ve güneş kontrol elemanının çeşidi ve konumu gibi parametrelere bağlıdır.

Çift tabakalı akıllı cephe sistemleri, tek veya çift camdan oluşan dış cephe, yalıtım sağlayan ve 20 ile $200 \mathrm{~cm}$ arasında değişebilen boşluk ve çift camlı iç cephe olarak üç ana bölümden oluşmaktadır. Cepheler arasındaki boşlukta doğal ve/veya mekanik havalandırma sistemleri ile farklı hava stratejileri oluşturularak yazın soğutma yükü ve kışın ısıtma yükü azaltılabilmektedir. Çift tabakalı cephe sistemlerinde hava stratejileri olarak cephenin alt kısmından menfezlerle alınan soğuk hava boşluk boyunca isınarak yükselmektedir. Soğuk havalarda boşlukta 1sınan hava 1sı yalıtımı sağlamakta ve istenildiğinde ısınan hava mekanik yollarla iç mekâna verilebilmektedir. Sıcak havalarda ise hava boşluğunda ısınan hava cephenin üst kısmındaki havalandırma kanalları ile dış ortama verilerek mekanın soğutma yükü azaltılmaktadır. Yüksek katlı ve/veya rüzgar etkisinin 
fazla olduğu ve iç mekanda kamaşma sorunun yaşandığg iklim bölgelerinde cepheler arasındaki boşluklara güneş kontrol elemanlarının yerleştirilmesiyle güneş kontrol elemanlarının dış etkenlerden korunması sağlanırken bakım ve onarım maliyetleri azaltılmaktadır.

\subsection{Akıllı Cephe Sistemlerini Oluşturan Bileşenler}

Akıllı cephe bileşenleri, cephenin 1sısal ve optik özelliklerini çevresel koşullara ve kullanıcı gereksinimlerine göre otomatik olarak değiştiren cam sistemleri, güneş kontrol elemanları ve cepheye entegre aktif sistemlerden oluşmaktadır.

\subsubsection{Cam Bileşeni}

Gelişen cam teknolojileri sayesinde cam sistemleri, değişen çevresel koşullar altında kullanıcının konforuna uygun olacak şekilde davranan ya da optik özelliklerini otomatik ya da manuel olarak değiştiren bileşenlerdir. Çalışma kapsamında akıllı cephe sistemlerinde kullanılan camlar, enerji etkin camlar ve akıllı camlar olarak iki grupta incelenmiştir (Şekil 1).

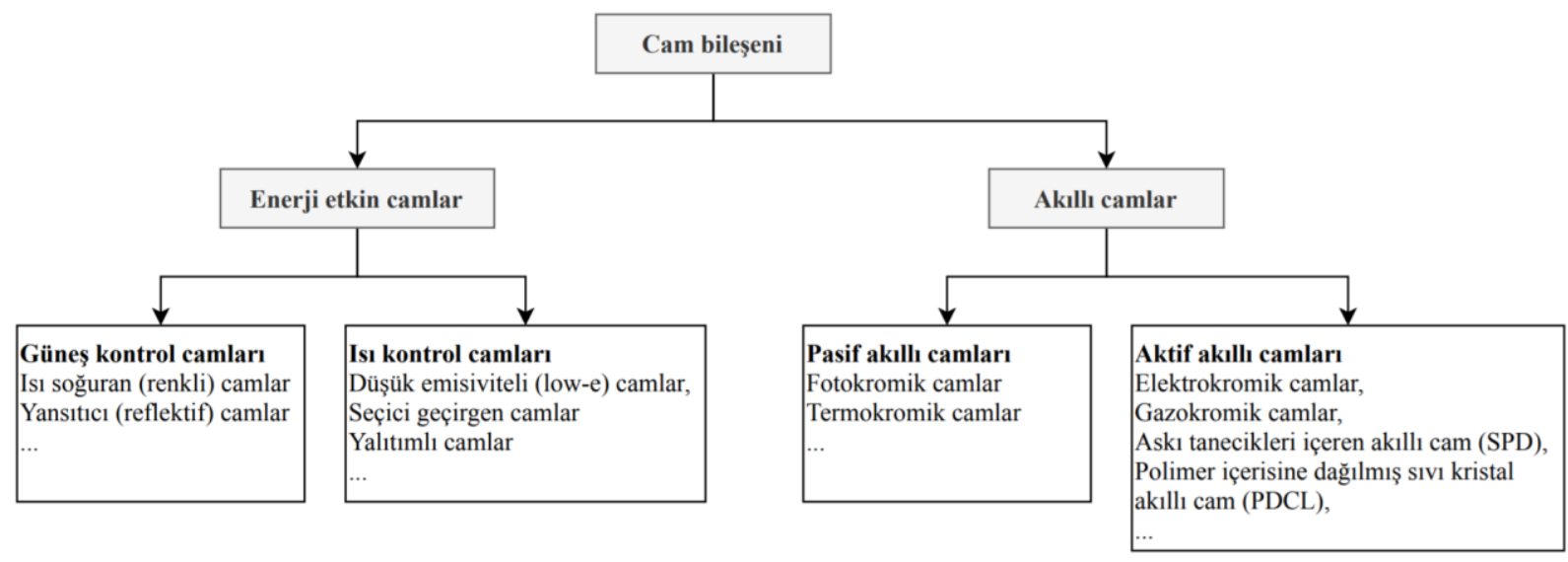

Şekil 1. Akıllı cephelerde kullanılan cam çeşitleri

Enerji etkin camlar; güneş ve 1sı kontrolü sağlarken dış etkenler karşısında yapısal olarak değişmeyen camlardır. Enerji etkin camlarda güneş kontrolü için 1sı soğuran (renkli) camlar, yansıtıcı (reflektif) camlar kullanılırken iklim kontrolü için düşük emisiviteli (low-e) camlar, seçici geçirgen camlar ve isı yalıtım amacıyla iki ya da daha çok tabakadan oluşan yalıtımlı camlar kullanılmaktadır.

Isı soğuran (renkli) camlar, float camın yapısındaki demir miktarının değiştirilmesiyle veya bir takım metal oksitlerin eklenmesiyle farklı renklerde camlar elde edilmektedir. Renkli camların float camlara göre daha fazla güneş 1şınımlarını soğurmasından dolayı cam yüzeyindeki sıcaklık artmaktadır. Bu camlarda güneş kontrol etkinliğinin ve/veya cam boyutlarının artmasıyla yüzeydeki gerilmenin artacağından temperlenerek kullanılması gerekmektedir [7]. Renkli camların güneş 1sı kazanç katsayısı düşüktür. Renkli camlar yalnızca güneşten gelen 1sıyı değil aynı zamanda 1şı̆̆ında büyük bir kısmını tutabilmektedir [8].

Yansıtıcı (Reflektif) camlar, üretim hattında veya üretim hattı dişında çeşitli metal veya metal oksitlerle yüzeyleri kaplanarak güneş 1şınımını yansıtma katsayısı yüksek ve geçirgenlik katsayısı düşük olan camlardır [9]. Güneş 1şığı geçirgenlik değerleri düşük olduğundan mekânda kullanıcı 
konforunu sağlamak için yapay aydınlatmaya ihtiyaç olabilir.

Low-e kaplamalı camlar, metal veya metal oksitlerle kaplanarak cam yüzeyinin iç veya diş kısmının uzun dalga boyuna sahip ışınları yansıtma özelliği kazandırılmış camlardır [10]. Low-e kaplamalı çift camlar, gün 1şı̆̆ı ve güneş ısısına geçirgen olması ve mekan içerisindeki sıcaklığın kaçışını engellemesi olumlu yönleri iken bulunduğu coğrafi konuma göre ek tedbirler alınarak kullanılması gerekebilir. Ilıman nemli iklim bölgelerinde sadece low-e kaplama yeterli olurken sıcak nemli iklim bölgelerinde güneş kontrol özelliklerine sahip kaplamalarla kullanılmalıdır.

Seçici geçirgen camlar, kullanıldığ 1 iklim bölgesi ve kullanıcı ihtiyaçlarına uygun olacak şekilde üretilmiş olup kızılötesi, morötesi veya görülebilir gibi ışınımlarının biri ya da birkaçını filtre edebilen camlardır [11].

Yalıtım camı, en az iki cam tabaka ve arasında ara boşluk çıtası, nem önleyici ve dolgu gazı bulunan ve cam tabakalarının çevresi hava geçirimsiz olacak şekilde yalıtımlarla kapatılmış cam sistemidir. Paneller arasındaki boşluk, 1sı veya ses yalıtımını iyileştirmek için kurutulmuş hava veya soy gaz içermektedir.

Akıllı camlar; çevresel etkiler altında yapısal özelliklerini değiştiren pasif akıllı camlar ve elektriksel uyarı altında yapısal özellik değiştiren aktif akıllı camlar olarak iki gruba ayrılmaktadır. Pasif akıllı camlardan fotokromik camlar, yapısındaki metal kristalleri sayesinde güneşten gelen UV ışınlarına maruz kaldığında 1şık geçirgenliğini azaltarak kamaşmayı ve mekanın ısınmasını önlemektedir. Fotokromik camlar, güneşten gelen 1şık geçirimi $\% 75^{\prime}$ ten $\% 25$ 'e ve güneş faktörünü $\% 53$ 'ten \% 23'e kadar düşürebilmektedir [12]. Fotokromik camların olumsuz yönü güneşli soğuk günlerde camın güneş 1şınları ile koyulaşmasıyla mekan içinde güneşten 1sı kazanımı azalacağından ısıtma ihtiyacı artmaktadır.

Termokromik camlar, tabakalar arasındaki özel jeller vasıtasıyla ortamın sıcaklığına bağlı olarak optik özelliğini ve rengini değiştirerek camın güneş 1şınlarına karşı yansıtıcı olmasını sağlayan ve mekanın ısıtma ve soğutma yükünü azaltan pasif akıllı cam sistemleridir. Faz geçiş sıcaklık aralığı genellikle $10^{\circ} \mathrm{C}$ ile $65^{\circ} \mathrm{C}$ arasındadır. Termokromik camların bir diğer avantajı ise sicaklığın artmasıyla mekana giren UV (mor ötesi) 1şınlara karşı geçirimsiz duruma gelmekte ve bu sayede mekan içindeki mobilya, döşeme ve duvar kaplamalarının renklerinde sararma ve solma gibi bozulmaları önlemektedir .

Termokromik camların olumsuz yönlerinden biri, kış aylarında dış ortam sıcaklığının, camın faz geçiş sıcaklığından az olduğunda ve güneşin yüksekliğinin azaldığı zaman diliminde artan 1şımalarla birlikte iç mekanda kamaşma ve aşırı 1sınma gibi sorunlar görülmektedir. Yazın ise dış ortam sıcaklığının yükselmesiyle iç ortama geçen 1 şık iletiminin azalması yapay aydınlatma ihtiyacina sebep olmaktadır $[13,14]$.

Elektrokromik camlar, elektriksel etki altında kaplama yüzeyindeki iyonların hareket etmesiyle camın rengi koyulaşırken camın güneş 1sı kazanç katsayısı (SHGC) ve 1şık geçirgenlik (Tvis) değerleri değişmektedir (Şekil 2), [15]. Elektrokromik camlara, kullanıcı tarafından elle ya da bina otomasyon sistemleri ile otomatik olarak camın bağlı olduğu elektrik devresinden 1 ile 5 volt arasında elektrik akımı verilmektedir. Elektrokromik camların şeffaf durumda 1şık geçirgenliği $\% 60$ 'tan iken opak olduğunda bu değer \%1, 1s1 kazanç değeri şeffaf durumda 0,46 iken opak durumda 0,06'a kadar azalmaktadır [16]. Gazokromik camlar, elektrokromik camlar gibi aktif akıllı cam sistemleri olup camın renklendirilmesi için cam katmanları arasında hidrojen ve oksijen gazları kullanılmaktadır. 


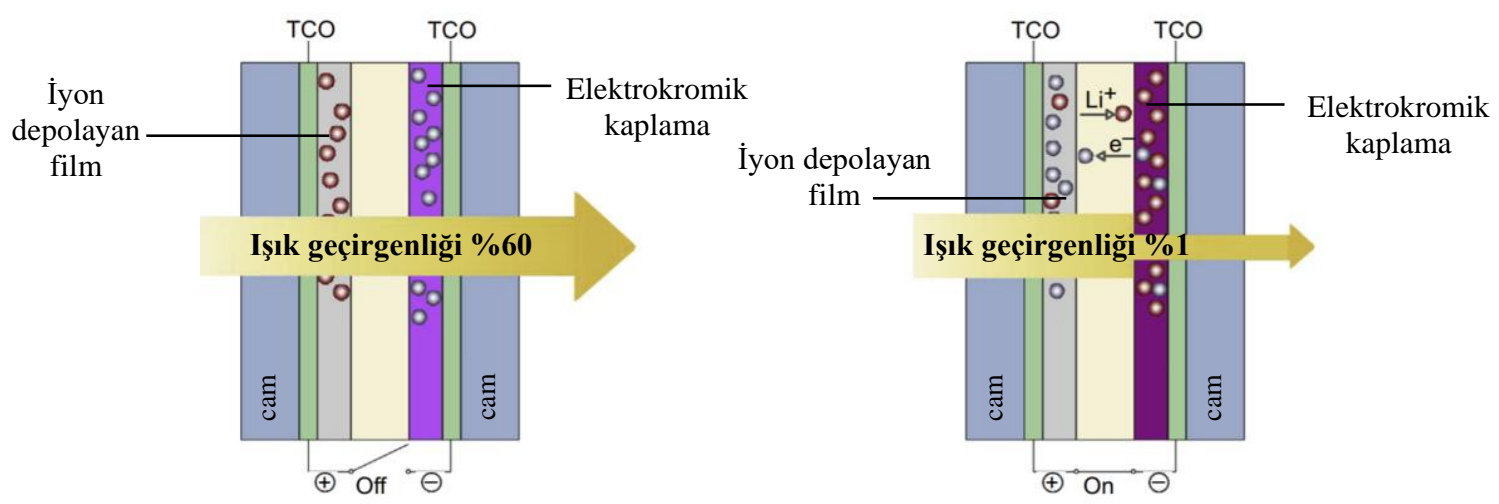

Şekil 2. Elektrokromik camın açık ve kapalı durumlar camların ışık geçirgenliği [16]

Diğer akıllı aktif cam sistemleri olarak askı tanecikleri içeren akıllı cam (SPD) ve polimer içerisine dağılmış sıvı kristal içeren akıllı cam (PDCL) sistemleri bulunmaktadır (Şekil 3). Bu sistemlerde cam tabakaları arasındaki alanda bulunan tanecikler ve kristaller elektrik akımı verilmediğinde dağınık olarak konumlandıklarından ışık geçirgenlikleri SPD camda \%5 ve PDCL camda \%50 iken sisteme elektrik akımı verildiğinde tanecikler düzgün olarak sıralanmasıyla SPD'de \%65 ve PDCL'de ise \%70 olmaktadır [16]. Bu camların olumsuz yanı elektrik akımı verilmediğinde camlar opak görünüme sahip olmasıdır.
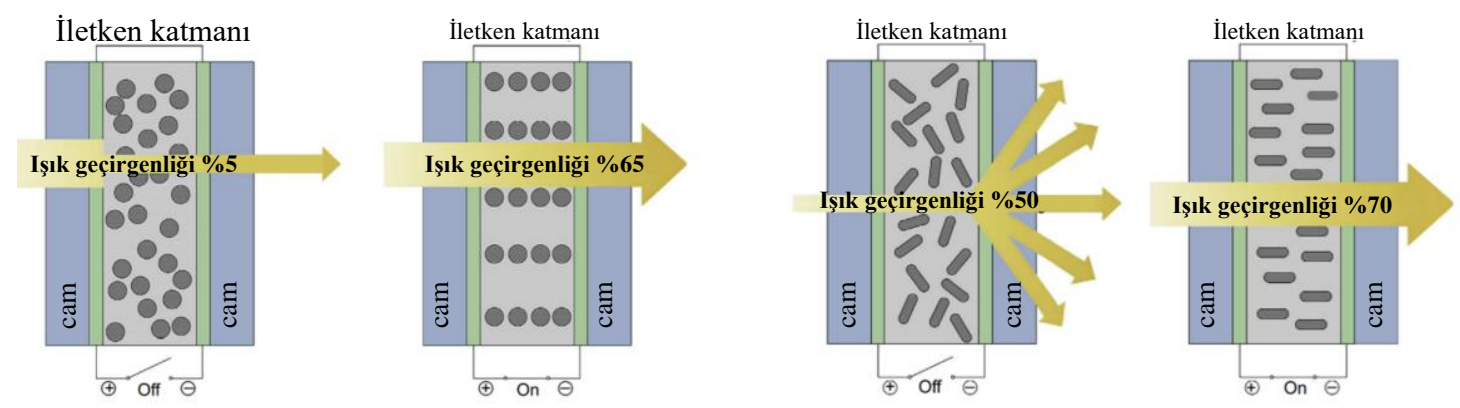

Şekil 3. SPD ve PDCL camların açık ve kapalı durumlar camların ışık geçirgenliğii [16]

\subsubsection{Güneş Kontrol Sistemleri}

Güneş kontrol elemanları cepheye doğrudan gelen güneş ışınlarını kısmen ya da tamamen engelleyerek mekan içindeki kamaşmayı önler ve 1sıtma-soğutma yükünü azaltır. Güneş kontrol elemanları cephenin dış yüzeyine, cam tabakaları arasına ya da cephenin iç yüzeyine yerleştirilebilir (Şekil 4). Dış tarafa yerleştirilen güneş kontrol elemanları, güneş ışınlarının cam yüzeyine ulaşmadan engellediğinden kamaşma ve soğutma sorununu önlemede etkin bir çözümken çevresel etkenlere doğrudan maruz kaldıkları için bakım-onarım maliyetleri yüksektir. Dış güneş kontrol elemanları ahşap, metal ve plastik esaslı malzemelerden yapılabileceği gibi cephedeki konumları sabit veya hareketli olarak tasarlanabilirler.

Çift tabakalı cephelerde cam yüzeyler arasındaki boşluklara yerleştirilen güneş kontrol elemanları; mekan içerisinde alan kaplamaması, bakım-onarım maliyetlerinin uygun olması ve çevresel etkenlere karşı korunması sistemin olumlu yönleridir. Bu cephe düzeninde cam yüzeyine eğik gelen ışınların iç mekâna dolaylı olarak ulaşırken dik gelen ışınlar engellenmektedir. Bu sebeple 
yazın mekanın 1sınmasına sebep olurken kışın ise 1sı kazanımı engelleyeceğinden kullanılan coğrafi konuma ve yöne dikkat edilmelidir. Cephe iç yüzeyine yerleştirilen güneş kontrol elemanları mekanda alan kaybına sebep olurken temizlik, bakım ve onarım maliyetleri düşük olmaktadır. Bu cephe düzeninin dezavantajı cam yüzeyine ulaşan güneş ışınlarından dolayı mekân ısısının artmasına ve kamaşmaya sebep olmaktadır. Bu sistemler otomatik ya da kullanıcı tarafindan elle kontrol edilebilmektedir.
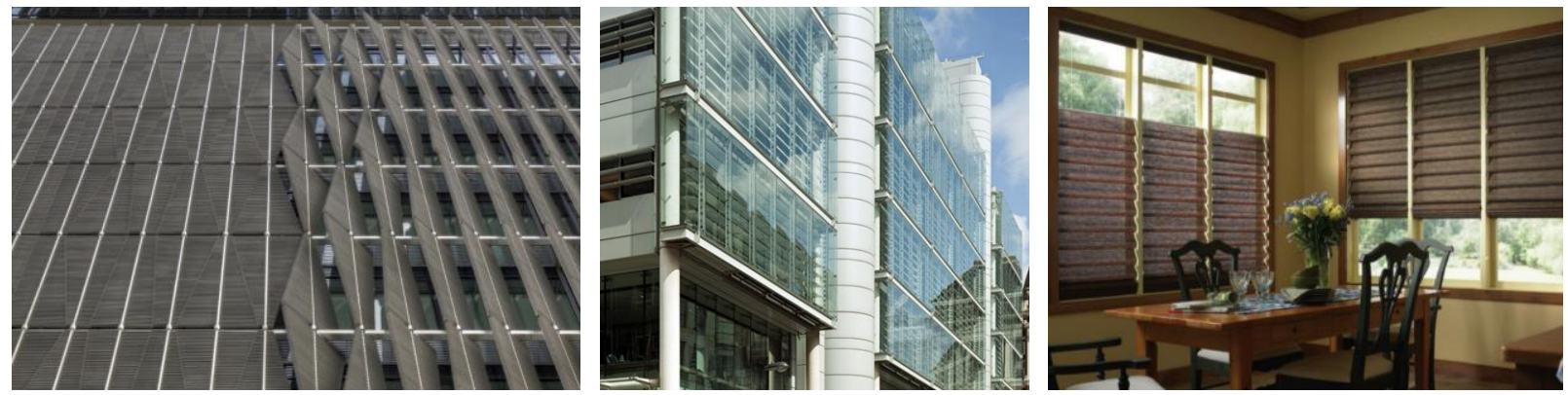

Şekil 4. Cephenin dış yüzeyine, cam tabakaları arasına ve cephenin iç yüzeyine yerleştirilen güneş kontrol sistemlerine ait örnekler cepheler $[17,18,19]$

Enerji korunumu kapsamında güneş kontrol elemanlarına yenilikçi yaklaşımlarla yeni malzeme ve teknolojik sistemler dahil olmaktadır. Bu yenilikçi yaklaşımlara örnek olarak Hoberman firması tarafından geliştirilen gölgeleme elemanları sayesinde geometrik formlarda hazırlanmış metal veya plastik paneller motorlar yardımıyla güneşin konumuna göre kinetik olarak çalışmaktadır (Şekil 5.a). Bu sayede kamaşma engellenirken mekanın 1sitma ve soğutma yükü azaltılabilmektedir. Malzemelerin gelişimi ile tasarlanan Homeostatik cepheler, çift tabakalı sistemlerde cam yüzeyler arasında iki tarafı gümüş elektrotlar ile kaplanmış yalıtkan şeritlerden oluşmaktadır. Bu şeritler ortamın 1sısının artmasıyla şeritler açılarak mekân içinde güneş kontrolü sağlarken yapının 1sı kaybını ve kazancını dengeleyerek enerji tasarrufu sağlamaktadır (Şekil 5.b). [20].
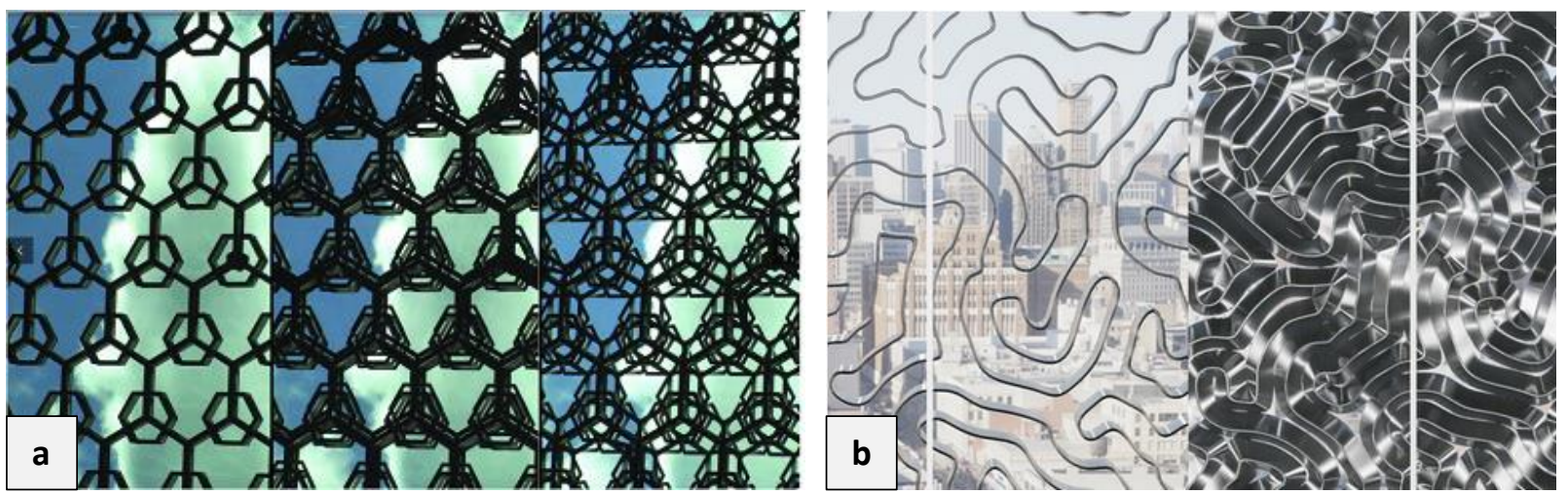

Şekil 5. a. Hoberman tarafından geliştirilen güneş kontrol elemanı, b. Homeostatik cephe sistemi $[21,22]$

\subsubsection{Akullı Cephe Sistemlerine Entegre Edilen Aktif Sistemler}

Cephe sistemlerine entegre edilen aktif sistemler sayesinde güneş, rüzgar gibi yenilenebilir enerji kaynaklarını 1S1 ya da elektrik enerjisine çevirerek yapı içerisinde depolayıp gerektiğinde kullanılabilmektedir. Çalışma kapsamında güneş, rüzgar ve biyokütle enerji kaynaklarının akıllı cephe sistemlerinde kullanımı için entegre edilen sistemler incelenmiştir. 
Güneş enerjisi, yapılarda kullanılan aktif sistemlerden güneş kolektör panelleri ile ısıtma enerjisi, fotovoltaik (PV) ve binaya entegre fotovoltaik (BIPV) panellerle güneş 1şığını elektrik akımına dönüştürerek elektrik enerjisi üretilebilmektedir [23]. Fotovoltaik paneller tasarıma göre bina kabuğuna, cam yüzeyine ya da güneş kontrol elemanlarına monte edilebilirken güneş kollektörlerinin 1sı yutucu levhaları cephe kaplaması olarak kullanılabilmektedir. Cephe kaplaması olarak güneş kolektörlerine örnek olarak 2016 yılında Ankara'da yapılan Türk Havacılık ve Uzay Sanayii A.Ş. Boya Atölyesinde $40 \mathrm{mx} 9 \mathrm{~m}$ boyutlarında duvar uygulaması ile yıllık $\mathrm{CO}_{2}$ salınımın azaltılırken her yıl ortalama $101.000 \mathrm{~m}^{3}$ doğalgaz tasarrufu yapıldığı belirtilmektedir [24].

Rüzgar enerjisini elektrik enerjisine çevirebilmek için yapılarda binaya monte ya da binaya entegre rüzgar türbinleri kullanılmaktadır. Binaya monte rüzgâr türbinleri, mevcut veya tasarım aşamalarında dahil edilebilir. Bina formu rüzgarın akışını değiştirmek ya da arttırmak amacı olmayan sadece iyileştirme yapılarak binanın kule görevi görmesi sağlanmaktadır [25]. Mevcut binaya monte rüzgar türbinleri sistemine CIS kulesi örnek verilebilir. 1962 yılında mozaik taş duvar kaplamalı CIS kulesinin cephesinin zamanla bozulması ve sürdürülebilir yapıya dönüştürülmesi kapsamında cephe fotovoltaik panellerle kaplanıp çatıya 17 metre yüksekliğinde 24 rüzgar türbini eklenmiştir (Şekil 6). Eklenen aktif sistemlerle yapının ihtiyacı olan enerjinin \%10'unu üretebilmektedir [26,27].
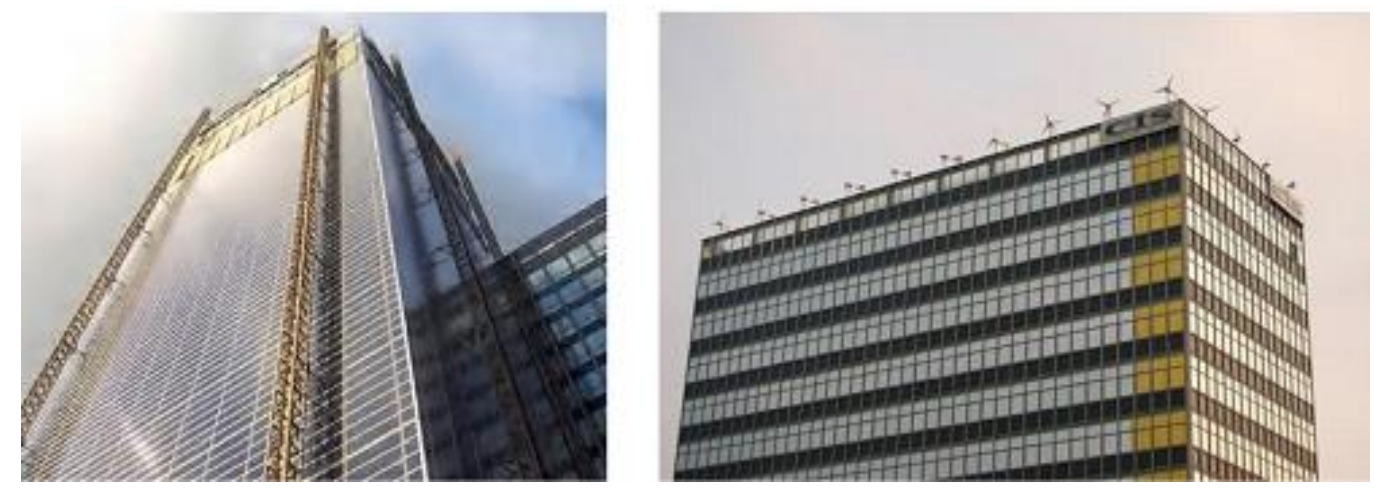

Şekil 6. CIS Kulesi [27]

Binaya entegre rüzgar türbinleri, tasarım aşamasında binanın formu ile rüzgarın yönünü, hızını ya da yoğunluğunu arttırarak üretilecek enerjinin en üst seviye yükseltilmesi hedeflenmektedir [25]. Binaya entegre rüzgar türbinleri, binaya mesnetli ve mesnetsiz olarak ikiye ayrılmaktadır. Bahreyn Dünya Ticaret Merkezi rüzgâr türbinlerinin binaya entegre edilen ilk yüksek katlı binasıdır. Rüzgâr türbinleri, Basra Körfezinden gelen hava akımı yönüne (kuzeye) yerleştirilmiş olup rüzgarın hız kazanması için binaya yelken formu verilmiştir (Şekil 7).
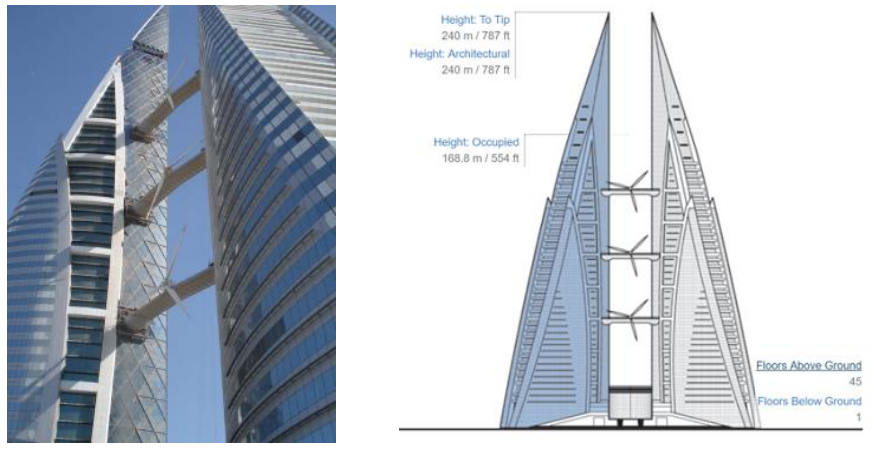

Şekil 7. Bahreyn Dünya Ticaret Merkezi [28] 
Biyokütle enerjisi, bitkilerin ya da su yosunu gibi canlıların fotosentez ile güneş enerjisini kimyasal enerjiye dönüştürerek oluşan biyokütlenin 1sı ve elektrik santrallerinde yakılmasıyla elde edilen enerji türüdür. Biyokütle günümüzde mimaride biyoreaktör cephe sistemleri ile hem enerji üretimi hem de yapıda gölgeleme sağlamaktadır. Cam panelleri arasına yerleştirilen algler büyümesi ve gelişimi için paneller arasında hava değişimi yapılmaktadır. Algler belirli sürelerde panellerden alınıp elektrik santrallerinde fermantasyon işlemiyle enerji üretimi sağlanmaktadır.

\section{Akıllı Cephe Sistemlerine Sahip Yapıların İncelenmesi}

Akıllı cephe sistemleri tabaka sayılarına, kullanılan bileşen özelliklerine ve yapı entegre edilen aktif sistemlere göre kendi enerjisini üretme, 1sı kaybını ve/veya kazancını dengeleyen ve kendini temizleyebilen gibi işlevlerden birini ya da birkaçına sahip olarak tasarlanmaktadır. Bu işlevler yapının coğrafi konumu, yüksekliği ve kullanıcı ihtiyaçlarına göre değişiklik gösterebilmektedir. Çalışma kapsamında seçilen örnek yapılar, akıllı cephe sistem bileşenlerine ve özelliklerine göre incelenmiştir. Sonuç bölümünde yapıların 1sısal, optik, havalandırma ve enerji üretimi işlevlerine göre kıyaslama yapılmıştır.

\subsection{Al Bahar Kuleleri}

Al Bahar Kuleleri, Abu Dabi Yatırım Konseyi için yapılan uluslararası mimari yarışma kapsamında tasarlanmış olup 2012 CTBUH ödülleri çerçevesinde CTBUH Yenilik Ödülü’nü kazanmıştır. Dünya'nın en büyük bilgisayar kontrolü ile çevre koşullarına cevap veren diş cephe kaplamasına sahiptir (Şekil 8). Abu Dabi'nin yazın $49^{\circ} \mathrm{C}$ sıcaklığa ulaşan çöl iklimi bölgesinde bulunmasından dolayı yapının formu, güneşin etki ettiği yüzey alanını azaltmak ve en az yüzey alanıyla en büyük hacmi sağlamak için dairesel formda tasarlanmıştır. Yapının formu, binanın alt ve üst kotlarında daralırken orta kısımlarda genişlemektedir [29, 30]. Al Bahar Kulelerinin akıllı cephe özellikleri aşağıda belirtilmiştir.

- Cephede kullanılan güneş kontrol elemanları, bölgesel mimariye özgü "Mashrabiya" formunun kağıt katlama sanatı olan origami ile birleştirilerek güneşin hareketlerine göre açılıp kapanan sistemlerden oluşturulmuştur, [31].

- Doğu, güney ve batı cephelerine yerleştirilen güneş kontrol elemanları, her bir kulede 1049 adet panelden oluşmaktadır. PTFE malzemeden yapılmış ve üzerinde mikro fiberglas kaplanan güneş kontrol elemanları giydirme cephe yüzeyi ile arasında 2 metre kalacak şekilde paslanmaz çelik çerçeveye monte edilmiştir. Güneş kontrol panellerinin yüksekliği $420 \mathrm{~cm}$ genişliği 360 ile $540 \mathrm{~cm}$ arasında değişmektedir. Panellerin her biri merkezi olarak yerleştirilmiş bir aktüatör ve piston aracılığıyla açılan altı üçgen çerçeveye bölünmüştür [32].

- Güneş kontrol elemanlarının servis süresi boyunca; $49^{\circ}$ dereceye kadar olan sıcaklığa, yüksek UV güneş 1şınlarına ve neme, korozyona, $\pm 3.5 \mathrm{kPa}$ ve $240 \mathrm{~km} /$ saate kadar yüksek rüzgâr yüklerine ve ana destek çerçevesi yangında 2 saate kadar dayanım göstermesi beklenmektedir [33].

- Al Bahar Kulelerinin giydirme cephesinde kullanılan çerçeve ve profillerin tamamı PVDF kaplamalı alüminyum malzemedir. Giydirme cephede kullanılan camların yapısal özellikleri gün 1şı̆̆ı geçirgenliği \%40, güneş 1Sısı kazanç katsayısı 0.28 , diş 1şı ğı yansıtma oranı \%18 ve camların U (1s1 iletkenlik) değeri $2.0 \mathrm{Wm}^{2} / \mathrm{k}^{\prime}$ dır [32,33]. 
- Çalışma saatleri içerisinde doğal aydınlatma düzeyi 250 ile 2000 lux arasında olması istenmekte ve aydınlık düzeyi 250 lux'un altına düştüğünde sensörlerle yapay aydınlatma sistemleri etkinleştirilmektedir [32].

Al Bahar kulesinin dinamik güneş kontrol sisteminin kamaşmayı önlemesi ve yapay ışığa olan ihtiyacı azaltması ile güneş 1şınımından kaynaklı 1sı kazancı $\% 50$ oranında azaltılırken yılda 1750 ton $\mathrm{CO}_{2}$ salınımını önlediği görülmektedir. Güneş kontrol panellerinde meydana gelen hasarlarda bozulan paneller kolaylıkla değiştirilebilmesi ve panellerin geri dönüşümlü olması ile atık üretimi azaltılmıştır. Al-Bahar kuleleri büyüklüğündeki yapılarda atık seviyesi \%30’a kadar çıkarken ortalaması olarak \%10 kabul edilmekte ve bu yapıda atık seviyesini $\% 3$ ile $\% 5$ seviyesine düşürülmüştür [31, 33].
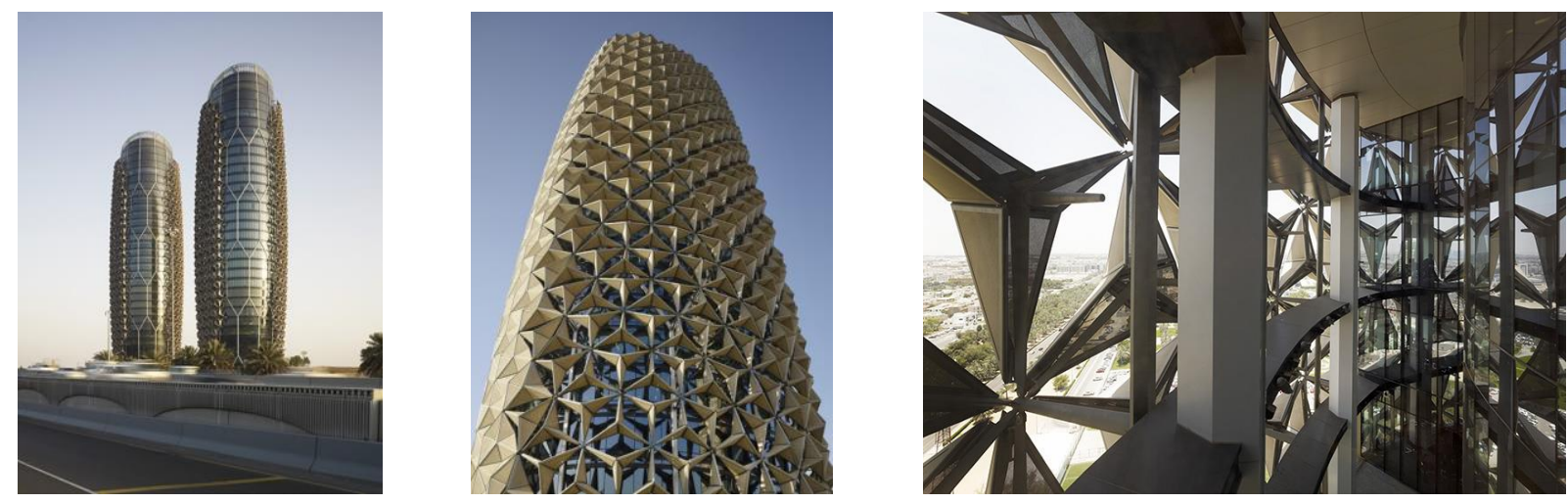

Şekil 8. Al Bahar kulelerinin dinamik güneş kontrollü cephesine ait fotoğraflar [34]

\subsection{Bir Okyanus- Tematik Pavyon}

Bir Okyanus- Tematik Pavyonu, 2012 yılında Avusturyalı mimarlık firması SOMA tarafından Yeosu Güney Kore'de yapılmıştır. SOMA tasarımın amacını "bir okyanusun çeşitli şekillerde Expo'da tematik temsilini gerçekleştirmek için gereken mekânları hazırlamak, ikonik bir kent simgesi oluşturmak ve kentsel bağlam ve çevreyle iletişim kurmak" olarak açıklamıştır. Okyanusun sonsuz yüzeyi ve derinliği tematik pavyon için ilham vermiştir [36].

Tematik pavyonun en önemli bölümü olarak kinetik akıllı cephesi kabul edilmektedir (Şekil 9). Mimaride form değiştirebilen sistemler genellikle sert elemanların ya da yumuşak tekstil malzemelerinin menteşe, rulo gibi elemanlarla hareket ettirilmesine dayanmaktadır. Yapının kinetik cephesi için cam elyaf takviyeli lamellerin kullanılması ve hareketleri için menteşe kullanılmadan doğadaki çiçeklerin açılıp kapanmasını ya da yaprak yönelimlerini yansıtan biyomimetik anlayış uygulanmıştır. Yapının akıllı cephesinin özellikleri aşağıda verilmiştir [37].

- 140 m uzunluğundaki kinetik medya cephesinde kullanılan lamellerin yüksekliği 3 ile 13 metre arasında değişmektedir. Kinetik cephe, 108 adet hareketli lamellerin bir kenarı sabit, diğer kenarı uzayabilen aktüatörler tarafından üst ve alt kenarlarından desteklenmesiyle oluşmaktadır. Lameller hem üst hem de alt kenarlarından aktüatörler tarafından sıkıştırma kuvveti ile elastik deformasyon oluşturarak iki rulman arasındaki mesafe azalmasıyla bükülme hareketiyle açık konuma gelmektedir.

- Kinetik cephe lamelleri iklim koşullarına göre otomatik çalışabildiği gibi kullanıcı ihtiyaçlarına göre farklı modlarda da çalıştırılabilir. Her bir lamel ayrı kontrol edilebildiği için cephede hareketli desenler oluşmaktadır. 
- Güney Kore kıyılarında etkili olan tayfunların oluşturacağı $35 \mathrm{~m} / \mathrm{s}^{\prime}$ ye kadar etkili rüzgar hızlarına dayanım gösterecek şekilde tasarlanmıştır. Rüzgârın hızı $12 \mathrm{~m} / \mathrm{s}$ 'den az olduğunda cephe çalışırken rüzgâr hızı $12 \mathrm{~m} / \mathrm{s}$ 'den fazla olduğundan cephe otomatik olarak kapanmaktadır.

Yapı hâkim rüzgâr yönüne göre konumlandırılması ile doğal havalandırma sağlarken akıllı cephe sistemi rüzgar hızına göre kendini otomatik olarak ayarlayabilmesiyle enerji korunumu sağlamaktadır. Enerji depolanabilmesi, havanın kapalı olduğu günlerde de sıv1 emmeli soğutucu klima ünitesi ve güneş kolektörleri ile güneş enerjisinden faydalanılabilmesi ve yeşil çatısı ile yenilenebilir enerji kaynaklarının kullanımı yönünden sürdürülebilir bir yapıdır [30].
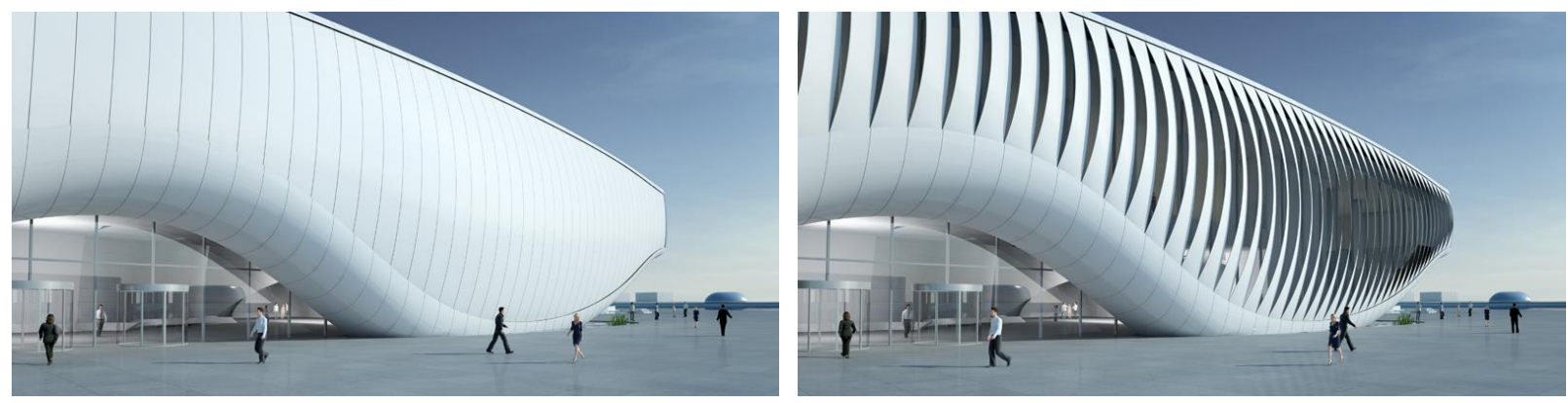

Şekil 9: Bir Okyanus- Tematik Pavyon yapısının kinetik akıllı cephesi [35]

\subsection{BIQ Binast}

İlk biyoreaktör cephesine sahip BIQ binası 2011-2013 yılları arasında Hamburg'daki Uluslararası Yapı Fuarında (IBA) bir pilot proje olarak tasarlanmış ve yenilikçi yaklaşımı sayesinde çeşitli ödüller kazanmıştır. Yapının amacı alg biyokütlesi ve güneş ışığını kullanarak yenilenebilir enerji üretimi için dinamik bir cephe sistemi oluşturmaktır [38].

Binanın güneydoğu ve güneybatı cephelerinde ikinci bir katman olarak 250x70 cm boyutlarında 129 adet biyoreaktör paneller kullanılmıştır (Şekil 10). Bu paneller sayesinde mekanlarda gölgeleme sağlanırken enerji üretilmektedir. Biyoreaktör panellerle BIQ binasında bulunan 15 dairenin toplam 1sıtma ihtiyacının yaklaşık 1/3'ü karşılanmaktadır. Dört tabaka camdan oluşan biyoreaktör panellerin içteki iki cam tabakanın arasında alglerin büyümesi için 24 litrelik bir boşluk ve bu camların her iki tarafına yalıtım amacıyla argon gazı ile doldurulmuş boşluklar bulunmaktadır. Boşluk ve argon gazı sayesinde ses yalıtımı sağlanırken 1sı kayıpları en aza indirilmiştir. Panelin öndeki cam tabakası beyaz yansıma önleyici cam iken arkasındaki cam tabakası dekoratif camdır [39]. Biyoreaktör paneller güneşin konumunu izlemek için kendi düşey eksenleri etrafında dönebilirler. Cam paneller arasında algleri büyümesi için sıvı besin ve karbondioksit kullanılırken mikroorganizmaların yerleşip çürümeye yol açmaması için panellere basınçlı hava pompalanmakta ve panellerin içindeki otomatik fırçalarla camlar temiz tutulmaktadır. Paneller güneş ışığını enerjiye dönüştüren güneş 1sısı kolektörü işlevi de görmektedir. Uzmanlara göre algler tarafından fotosentez için kullanılmayan güneş enerjisi sistemde isıya dönüştürülerek sıcak su olarak hemen kullanılabileceği gibi depolanabilme imkanı da bulunmaktadır. Panellerden düzenli olarak toplanan algler yerel enerji şirketlerine satılarak biyokütlenin işlenmesi sonucunda açığa çıkan metan gazından elektrik üretilmektedir [40]. 

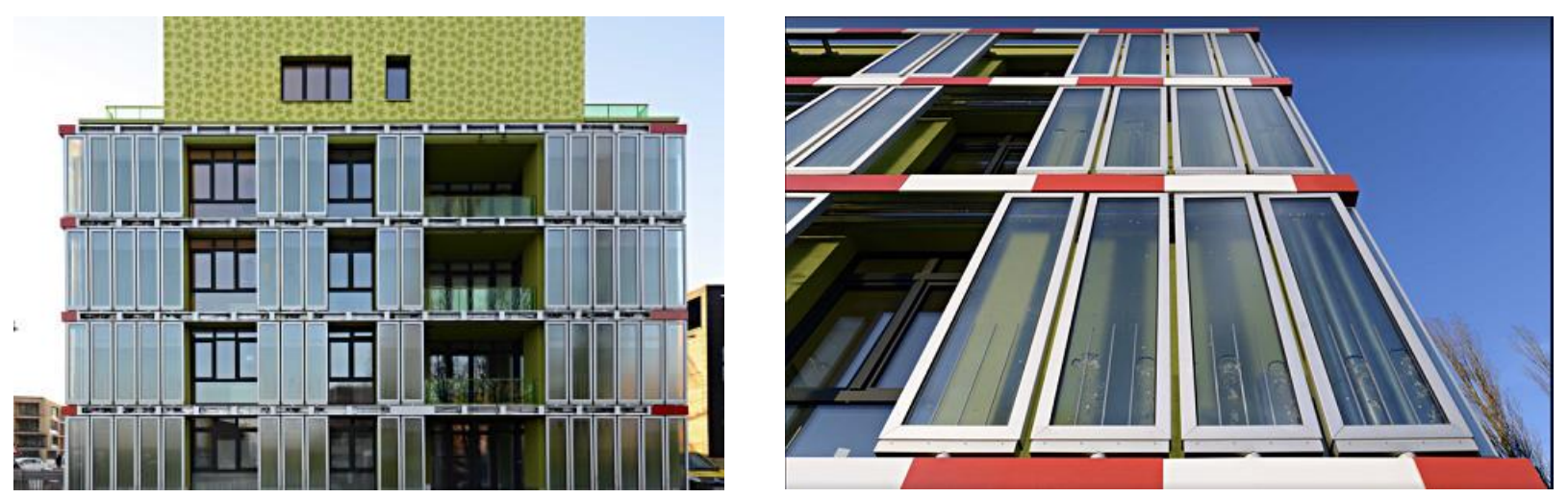

Şekil 10. BIQ Binası [41]

\subsection{Arap Dünyası Enstitüsü}

Arap Dünyası Enstitüsü binasının yapımı 1980 yılının başında Arap Devletleri ve Fransa tarafından ortaklaşa finanse edilerek Seine Nehrinin kıyısında 1987 yılında inşa edilmiştir. Enstitünün 62,4 m x 26 m ebatlarındaki güney cephesi, gün 1şığı geçirgenliği 0.10 ile 0.30 arasında olan ve elektropnömatik mekanizmalar vasıtasıyla açılıp kapanabilen 27.000 adet alüminyum diyaframdan oluşmaktadır (Şekil 11). Bu elemanlar fotoelektrik hücreler ile yerleştirilmiş ve bilgisayarla kontrol edilmektedir. Bu hassas mekanizmayı korumak için, $240 \mathrm{~m}^{2}$ alana sahip, $1.8 \times 1.8 \mathrm{~m}$ boyutlarında $40 \mathrm{~cm}$ genişliğginde çift cidarlı sistem geliştirilmiştir [19,4]. Diyagram sisteminin çalışma prensibi güneş karşısında göz bebeğinin davranışı ya da kamera lensinin hareketine benzetilmektedir. Cephenin orijinal tasarımında diyagramlara gelen 1 şık şiddetinin yoğunluğuna göre her biri bağımsız olarak hareket edecek şekilde tasarlanmıştır. Bakımlarının pahalı olması ve bazı diyagramların çalışmasında yaşanan sorunlardan sonra merkezi olarak bilgisayar denetimi ile kontrol edilecek şekilde düzenleme yapıllmıştır [20].
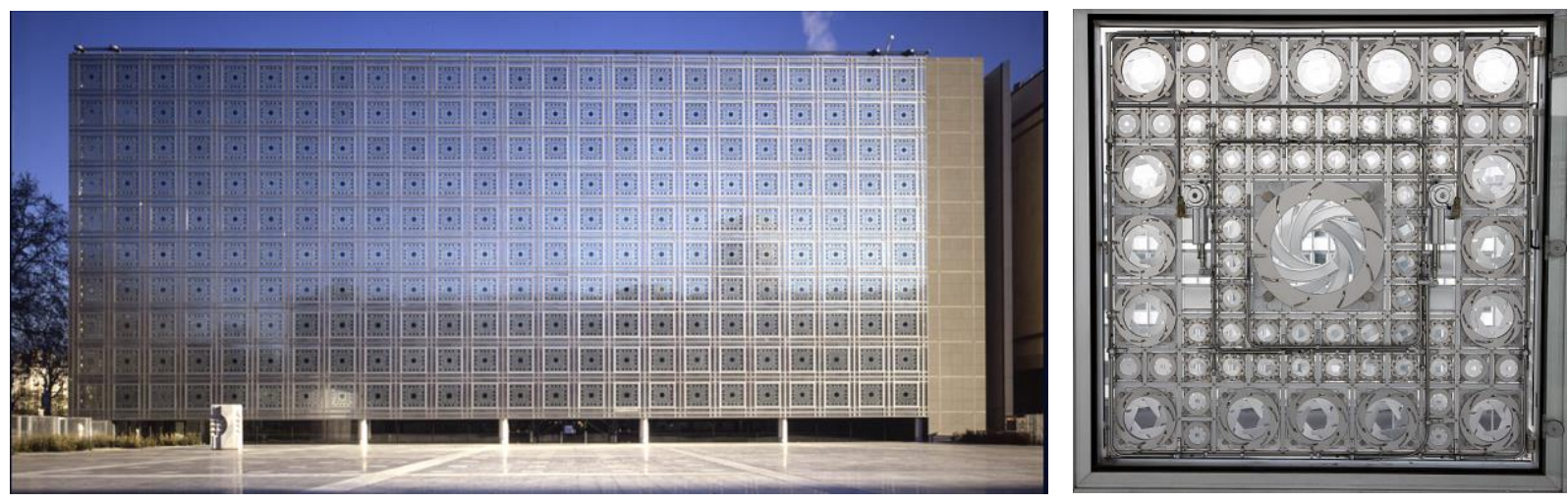

Şekil 11. Arap Dünyası Enstitüsü [43]

\subsection{Kiefer Sergi Salonu}

Ernst Giselbrecht tarafindan yapılan Kiefer sergi salonu projesi Avusturya'da 2007 y1lında tamamlanmıştır. Yapının güney cephesi, çevre koşullarına göre otomatik hareket eden yatay menteşe sistemiyle açılıp kapanabilen alüminyum güneş kontrol panellerinden oluşmaktadır (Şekil 12). Kişisel ihtiyaçlar doğrultusunda paneller bağımsız hareket ettirilebildiği gibi yap1 kullanılmadığı dönemlerde optimizasyon programları ile kontrol edilebilmektedir. Akıllı cephe 
sistemi, yapıda iç mekan ısı ve ışık kontrolü 56 adet motora bağlanmış 112 gölgeleme elemanının kayma hareketine dayanmaktadır [44]. Her panelin hareket ettirmek için ayrı bir elektrik motorunun bulunmasından dolayı yapım maliyeti yüksek olmasına karşın bakımı ve bozulan parçaların değiştirilmesi daha kolaydır. Sürdürülebilirlik açısından bakıldığında alüminyum panellerin hafif olmasına karşın açma kapama hareketlerini yer çekimi yönünün tersine doğru yapmasından dolayı enerji kullanımı artmaktadır.
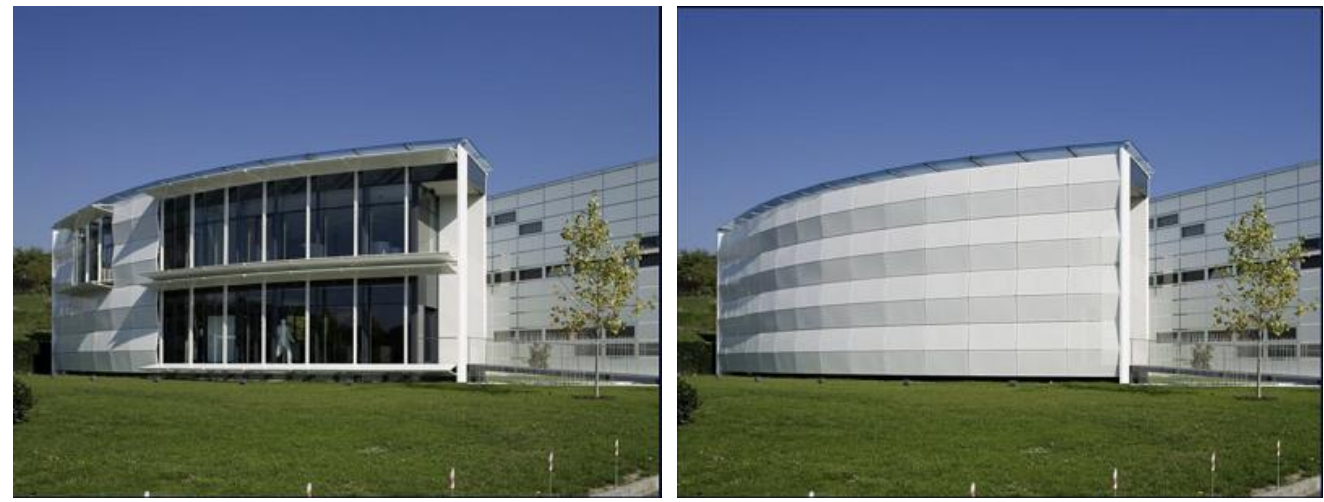

Şekil 12. Kiefer sergi salonu binası [45]

\subsection{Pearl River Kulesi}

Çin'in Guangzhou bölgesinde 2011 yılında yapılan Pearl River kulesi, 71 katlı olup ofis ve ticaret merkezi olarak SOM tarafından tasarlanmıştır. Pearl River Kulesi, Çin'in ilk sıfır enerji tüketen kulesi fikriyle geliştirilmiş olup sıcak ve nemli bölge koşullarında yenilenebilir enerji kaynaklarından aktif ve pasif olarak yararlanan ve kendi enerjisini üreten bir gökdelendir [45].

Pearl River kulesi, hakim rüzgarın güney yönünde esmesinden dolayı rüzgar ve güneş enerjisinden aktif ve pasif olarak faydalanmak için ana cephe güney-güneydoğu yönünde konumlandırılmıştır. Cepheye entegre rüzgar türbinlerine ulaşan rüzgarın hızını arttırmak için iç bükey bina cephe tasarımı ile rüzgârın binadaki iki rüzgâr tüneline doğru akışı sağlanmaktadır (Şekil 13). Cephede rüzgârın akışı için bırakılan boşluklar sayesinde yapıya etki eden rüzgar yükü azaltılmıştır. Binanın elektrik enerjisi; rüzgâr türbinleri, cepheye entegre edilmiş güneş pilleri ve doğal gazlı yakıt pillerinden elde edilmektedir. Yapının güney cephesi, low-E kaplamalı camlar arasında otomatik olarak ayarlanan jaluzilerin bulunduğu çift tabakalı cephe sistemine sahip olup havalandırma mekanik sistemlerle gerçekleştirilmektedir. Güneş ışığının açısına ve şiddetine göre jaluzilerin otomatik ayarlanmasıyla kaliteli bir aydınlatma sağlanırken ısı kazanımı, yapay aydınlatma ihtiyacı ve HVAC gereksinimini azaltılmaktadır [26].

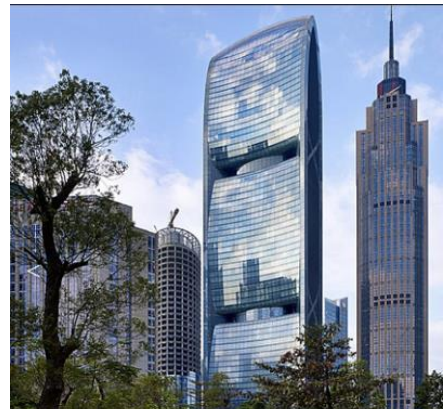

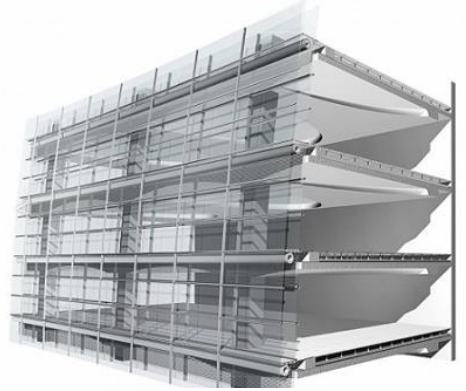

Şekil 13. Pearl River Kulesi

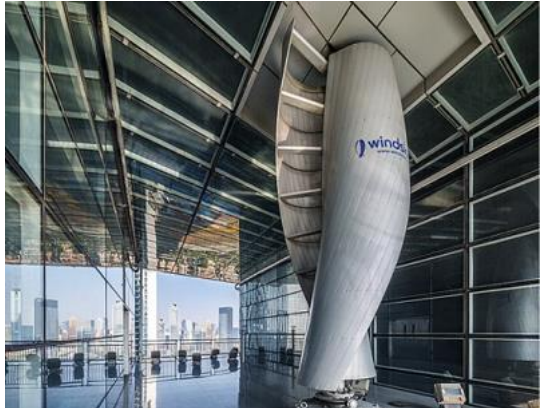




\section{Değerlendirme ve Sonuç}

Son yüzyılda yaşanan teknolojideki gelişmeler ile çevresel ve enerji sorunlarına karşı geliştirilen akıllı cephe sistemleri sayesinde çevresel koşullara göre kullanıcı konforunu en üst seviyede tutarken yapının 1sıtma, soğutma ve havalandırma gibi sistemler için kullanılan enerjiyi azaltan hatta yenilenebilir enerji kaynaklarını elektrik ve ısı enerjisi haline çevirerek yapının ihtiyaçlarını karşılayan ve yapının yaşam süreci boyunca oluşturacağı çevresel sorunları azaltan sistemler geliştirilmiştir. Çalışmada incelenen örnekler sonucunda yapının yapıldığı coğrafi konuma ve iklimsel özelliklerine göre yapıyı etkileyecek etkilerin öncelikle belirlenmesi ve bu etkilere cevap veren akıllı cephe sistem bileşenleri ile cephe düzeni kurulmalıdır. Çalışma sonucunda;

- Güneş 1şımalarının fazla olduğu bölgelerde kamaşma sonucunda kullanıcı konforunun azalması, mekân sıcaklığının yükselmesi ve soğutma yükünün artması gibi sorunlar ile karşılaşılmaktadır. Bu sorunları önlemek için mekanlarda enerji etkin cam ya da akıllı cam sistemleri kullanılmalıdır. Bu önlemlerin yetersiz olması durumunda cephe sisteminde çevresel etkilere uygun güneş kontrol elemanları ile kullanıcı konforu ve enerji korunumu sağlanmalıdır. Güneş kontrol sistemleri, Kiefer Sergi Salonu ve Okyanus Tematik Pavyon'undaki gibi hem manuel hem de otomatik çalıştırılabileceği gibi Al Bahar Kulelerinde ve Arap Dünyası Enstitüsü'ndeki gibi sadece çevresel veriler doğrultusunda otomatik çalışabilmektedir. İklimsel açıdan Al Bahar kulelerinde kamaşmanın daha fazla olması ve uygulanan güneş kontrol sistemi ile ısı kazancında \%50 azalma görülürken yıllık 1750 ton $\mathrm{CO}_{2}$ salınımı engellenmiştir.

- Akıllı cephe sistemlerine entegre edilen aktif sistemler sayesinde yapıya etki eden rüzgar ve güneş gibi yenilenebilir enerji kaynaklarını elektrik ve/veya 1sı enerjisine dönüştürerek yapının kaynak tüketimini ve $\mathrm{CO}_{2}$ salınımını azaltılabilmektedir. Aktif sistemleri entegre ederken doğru sistem seçimi ve doğru yapı tasarımını yapmak önemlidir. $240 \mathrm{~m}$ yüksekliğindeki Bahreyn Ticaret Kulelerinde mevcut rüzgâr hızını arttırmak için yelken formu kullanılırken 310 metre yüksekliğindeki Pearl River Kulesinde iki rüzgâr tüneli kullanılmıştır. Pearl River Kulesindeki rüzgâr yırtıkları, aynı zamanda bina yükseldikçe sorun haline gelmeye başlayan rüzgâr basıncını da düşürerek rüzgâr salınımlarını azaltmaktadır.

- Yapının arsa üzerinde doğru konumlandırılması yapının çevresel etkilere karşı dayanımını arttırırken yenilenebilir enerji kaynaklarının kullanımını sağlar. Pearl River Kulesinde yapı güney-güneydoğu arasında konumlandırılması ile etkili rüzgâr ve güneş enerjisini etkin bir şekilde kullanılmıştır.

- Yapıda kullanılacak bileşenlerin çevre ve birbirleriyle olan etkileri göz önünde tutularak tasarım yapılırsa yapım ve kullanım süresinde oluşan bakım maliyetleri ve atık üretimlerinde azalma sağlanabilir.

- Al Bahar Kulesinde mesai saatleri içerinde kuzey cephesine güneş 1şınımları fazla olmadığı için güneş kontrol elemanlarının uygulanmaması ve diğer cephelerde kullanılan güneş kontrol elemanları sayesinde yapılan hesaplamalar sonucunda giydirme cephede kullanılacak camların 1sı iletkenlik değerinin düşük olması gerektiği için kullanılan camların maliyeti azalmıştır.

Seçilen örnekler her biri farklı coğrafi konum ve iklim özelliklerine sahip yapılarda kendi ait çevresel koşullara cevap verecek şekilde tasarlanmış akıllı cephe sistemlere sahiptir. Teknolojinin gelişmesiyle birlikte cepheler çevresel koşullarda direnen statik halinden çevresel etkileri değerlendiren, onlara anında cevap veren ve aktif sistemler ile çevresel etkileri yapı için kullanabilen kinetik sistemler haline gelmeye devam etmektedir. 


\section{Kaynakça}

[1] Harrison, A. Intelligent Buildings In South East Asia. London: Routledge; 1988, syf. 1-4.

[2] Karasu, D. Akıllı Bina Yapı Bileşenleri: Duvar ve Döşeme Sistemleri, YL Tezi, Gazi Üniversitesi FBE, Ankara, 2004.

[3] Özler, M. E. Akıllı Binalarda Enerji Etkin Tasarım Parametreleri, YL Tezi, İTÜ FBE, İstanbul, 2003.

[4] Erturan, B. Akıllı Cephe Tasarım İlkeleri ve Uygulama Örneklerinin İncelenmesi, İstanbul: YL Tezi, MSGSÜ FBE, 2010.

[5] Orhon A. V. Ak1llı Malzemelerin Mimarlıkta Kullanımı. Ege Mimarlık (82), 2012, syf. 18-21.

[6] Orhon, A.V. Akıllı Yapı Kabukları, 11. Ulusal Tesisat Mühendisliği Kongresi Bildiriler Kitab1, 2013, syf. 1481-1487.

[7] Compagno, A. Intelligent Glass Façades, Birkhauser - Publishers for Architecture, Berlin, 2002.

[8] Borch, I.T., Keuning, D., Melet, E., Kruit, C., Peterse, K., Vollaard, P., Vries, T. ve Zijlstra, E. Skins for buildings : the architect's materials sample book, BIS Publishers, Amsterdam, 2004.

[9] Ünal, M. Çift Kabuk Cephelerin Sistematik Analizi ve Uygulama Örneklerinin incelenmesi, İstanbul: YL Tezi, MSGSÜ FBE, İstanbul, 2006.

[10] İlhan, Y. ve Aygün, M. Cephe Sistemlerinde Kullanılan Yalıtım Camı Kombinasyonları. 2526 Mart 2005, Çatı Cephe Fuarı, İstanbul, 2005.

[11] Ayçam, İ., Utkutuğ, G.S. Farklı Malzemelerle Üretilen Pencere Tiplerinin Isıl Performanslarının İncelenmesi ve Enerji Etkin Pencere Seçimi. IV. Ulusal Tesisat Mühendisliği Kongresi ve Sergisi, İzmir, 1999.

[12] Trajanoska, B., ve E. Doncheva. Influence of structural glass on working environment quality and healthcare benefits. Journal of Environmental Protection and Ecology, 2019.

[13] Addington, D. M., Schoedek, D. S. Architecture, Encyclopedia of Smart Materials: Volume 1 and Volume 2, ed. Mel Schwartz, John Wiley \& Sons, New York, 2005, syf. 59-67.

[14] Döşemeciler, A. Cam ve Aydınlatma Sistemlerinde Akıllı Malzemeler, Ege Mimarlık, Aralık 2012, syf. 14-17.

[15] Tavil, A. Cephe Sistemlerinde Yeni Teknolojiler Elektrokromik Pencereler. Ulusal Yap1 Malzemesi Kongresi ve Sergisi, İstanbul, 2004, syf. 111-116.

[16] Casini, M. Dynamic glazing. Smart Buildings, 2016, syf. 305-325.

[17] http://www.archdaily.com/?p=326747, (Erişim Tarihi: 15.01.2019)

[18] http://www.sheppardrobson.com/architecture/view/helicon-ec2, (Erişim Tarihi: 10.02.2015)

[19] https://www.txsunandshade.com/gallery/\#interior-solar-screens-desktop-bookmark (Erişim Tarihi: 29.06.2020)

[20] Edupuganti, S. R. Dynamic Shading: An Analysis, University of Washington, 2013.

[21] https://www.hoberman.com/portfolio/dynamic-windows/ (Erişim Tarihi: 17.09.2020)

[22] https://materialdistrict.com/article/homeostatic-facade-system/\#moved (Erişim Tarihi: 17.06.2020)

[23] Çelebi, Gülser. Bina Düşey Kabuğunda Fotovoltaik Panellerin Kullanım İlkeleri. Gazi Üniversitesi Mühendislik-Mimarlık Fakültesi Dergisi, 2002, 17.3: 17-33.

[24] https://solarwall.com.tr/brosur/tai.pdf (Erişim Tarihi: 25.09.2020).

[25] Günel, M. H.; Ilgın, H. E. Bir mimari tasarım kriteri olarak rüzgar enerjisi kullanımı. Ege Mimarlık Dergisi, 2008, syf. 6-11. 
[26] Zinzade, D. Yüksek Yapı Tasarımında Sürdürülebilirlik Boyutunun İrdelenmesi, İstanbul: YL Tezi, İTÜ FBE, İstanbul, 2010.

[27] Demir, N. (2011). Yüksek Yap1lar ve Sürdürülebilir Enerji. İstanbul: YL Tezi, YTÜ FBE.

[28] http://www.skyscrapercenter.com/building/bahrain-world-trade-center-1/998(Erişim Tarihi: 24.09.2020)

[29] http://www.webcitation.org/query?url=http\%3A\%2F\%2Fen.wikiarquitectura.com\%2Findex .php\%2FAl_Bahar_Towers (Erişim Tarihi: 05.02.2015)

[30] Başaran, Ö. Kinetik Gölgeleme Elemanları Entegre Edilmiş Bir Binanın Enerji Etkinliğinin Arttırılmas1, YL Tezi, Gazi Üniversitesi FBE, Ankara, 2015.

[31] http://www.ctbuh.org/TallBuildings/FeaturedTallBuildings/FeaturedTallBuildingArchive

2012/AlBaharTowersAbuDhabi/tabid/3845/language/en-US/Default.aspx adresinden (Erişim

Tarihi: 02.02.2014)

[32] http://content.iospress.com/articles/journal-of-facade-design-and-engineering/fde0040)

(Erişim Tarihi: 09.03.2015)

[33] https://duranvirginia.wordpress.com/2013/04/18/curiosities-11-buildings-with-unusual-

facades/ (Erişim Tarihi: 08.02.2015)

[34] https://www.e-architect.co.uk/dubai/al-bahar-towers-abu-dhabi (Erişim Tarihi: 28.09.2020)

[35] http://www.soma-architecture.com/index.php?page=theme_pavilion\&parent=2\#

(Erişim Tarihi: 28.09.2020)

[36] http://www.webcitation.org/query?url=http\%3A\%2F\%2Fwww.mimdap.org\%2F\%3Fp\%3D7 8891\&date=2015-02-05 (Erişim Tarihi: 05.02.2015)

[37] Knippers, J., Scheible, F., Oppe, M., Jungjohann, H. Kinetic Media Façade Consisting of Gfrp Louvers. CICE (Canada International Conference on Education), Roma, İtalya, 2012.

[38] http://www.iba-hamburg.de/en/projects/the-building-exhibition-within-the-building-

exhibition/smart-material-houses/biq/projekt/biq.html(Erişim Tarihi: 21.04.2017)

[39] http://www.webcitation.org/query?url=http\%3A\%2F\%2Fwww.coltinfo.de\%2Ftl_files\%2F pdf\%2FSonnenschutz\%2FSolarLeaf-bioreactor-facade.pdf (Erişim Tarihi: 06.02.2019)

[40] http://www.webcitation.org/query?url=http\%3A\%2F\%2Fwww.epsikiyatri.com\%2 Fenerji sini-alg-yetistirerek-saglayan-bina-43651 (Erişim Tarihi: 06.02.2019)

[41] https://archello.com/project/solarleaf (Erişim Tarihi: 25.09.2020).

[42] Murray, S. C. Contemporary Curtain Wall Architect. New York: Princeton Architectural Press. 2009.

[43] https://www.imarabe.org/en/architecture (Erişim Tarihi: 25.09.2020).

[44] http://www.architonic.com/aisht/dynamic-facade-kiefer-technic-showroom-ernst-

giselbrecht partner/5100449 (Erişim Tarihi: 03.02.2019)

[45] https://archello.com/es/story/2603/attachments/photos-videos/11?fullscreen=1

(Erişim Tarihi: 26.09.2020). 